\title{
A Study on the Plan for the Creation of a Child Friendly City according to the UN Convention on the Rights of the Child
}

\author{
Young-Hee Lee ${ }^{1}$, Mi-Na Lee ${ }^{2}$ \\ ${ }^{1}$ Adjunct Professor, Department of Social Welfare Counseling, Chodand University, South Korea, \\ lea0315@hanmail.net \\ ${ }^{2}$ Professor, Department of Welfare Counseling Convergence, Kwangshin University, Gwangju, South \\ Korea,lmn4780@naver.com
}

Corresponding author: Mi-Na Lee

\begin{abstract}
This study aims to investigate whether children and adolescents are living with a sense of satisfaction in life by recognizing their rights in the current residential environment in the local community Remove. In addition, the six areas of child-friendly cities are analyzed in detail so that they can be constructively and specifically supplemented for child-friendly cities. A total of 505 children and adolescents were surveyed from G city B district. As a result of the analysis, first, it was found that elementary school students had higher awareness of children rights and satisfaction than middle school, high school, and out-of-school students. Second, the rights of children that affect satisfaction were found in the order of family environment, educational environment, Insert conjunction and before health and social services. Third, the rights of children that affect satisfaction differed according to the school level. Elementary school students' level of satisfaction was in the order of home environment, educational environment, environment, and play and leisure, while middle and high school students were home environment, educational environment, and safety and protection. Out of school students' level of satisfaction was in the order of home environment, play and leisure, and health and social services. Based on the results of the study, it is suggested that a comprehensive intervention and approach to plan considering various aspects of education, safety and protection, play and leisure, health and social services, etc. should be implemented to create a child-friendly city.
\end{abstract}

Keywords: Child Friendly City, Children Rights, Satisfaction of Life, Creation of a Friendly City, UN Convention on the Rights of the Child.

\section{Introduction}

\subsection{The Necessity of Research}

All children and adolescents, as members of our society and leading the future society, have the right to achieve their full potential in a safe environment. Depending on how children and adolescents are perceived, protection of their rights have a profound impact on their growth and character formation. The rapid development of industrialization and urbanization today also increased the number of children and adolescents living in cities. Continued urbanization will accelerate and by $2025,60 \%$ of children worldwide will live in urban environments[1]. As a result, the daily life experiences of children and adolescents are created in the urban environment and face many different positive and negative aspects

Received: October 09, 2020; 1st Review Result: November 26, 2020; 2nd Review Result: January 13, 2021 Accepted: February 26, 2021 
of urbanization[2]. On the positive side, children and adolescents living in cities can grow up experiencing physical environments such as advanced transportation systems, efficient services, residential stability, drinking water and toilet use[3]. However, the negative impacts such as, the narrowness of residential space, environmental pollution, lack of play space, and indifference to community neighbors also undermine the satisfaction of children and adolescents' lives. Furthermore, cities are more threatened with various crimes and violence especially in dense areas[4]. Recently, the international community has been making a lot of efforts to improve the country with interest in creating an optimal living environment for children who are suffering from a risk of growth development to grow healthy. In line with the expansion of women's social advancement, the low birth rate began as a solution to the inadequate social environment of Hyphenate child-care. As such, the concept of "child and youthfriendly city" for children has been established from the perspective of child welfare, and is spreading throughout the region and around the world. The purpose of the child-friendly city is to minimize the negative effects of each community and urban environment on the growth and development of children and to achieve a sustainable development direction by promoting the rights of children. This is to create an environment in which all children and adolescents can live in a safe and clean environment where their rights are Insert comma after the word and their individual potential is fully utilized. It also refers to the fact that children and teenagers enjoy their rights and live happily in an environment that allows them to receive sufficient social services. Child Friendly Cities (CFC) refers to a city in which the four universal rights of children and adolescents - the right to live, to develop, to protect and to participate are fully realized in accordance with the ideology of the United Nations Convention on the Rights of the Child[5]. UNICEF (1996) emphasized that children and adolescents are special beings in urban environments and that children and youth-friendly cities are obliged to actively practice for future generations of growth with a sense of life satisfaction. Based on this point, many countries around the world are making efforts to improve the growth environment of children and adolescents suitable for each country's situation in order to practice child and youth-friendly cities.

Currently, 1,300 cities in 30 countries around the world are seeking more advanced ways to create a child- and youth-friendly city by sharing cases. As such, efforts are being made to create an environment suitable for the growth environment of children and adolescents in many countries and cities. The nation also continues to discuss the creation of an environment for the satisfaction of the lives of children and adolescents, breaking away from the policies for the development of growth and development of each community. Therefore, Korea is certifying a child-friendly city to create a community where the Convention on the Rights of Children is realized at the UNICEF Korea Committee established on January 1, 1994. In November 2013, Seong buk-gu, Seoul was certified as Korea's first child-friendly city while Wanju-gun is the certified CFC model for small and medium-sized cities. So far, 99 local governments across the country are creating UNICEF child friendly cities.

The child-friendly city movement has a lot of influence on the satisfaction and happiness of children at the community level. Community and residential regional effects in child and adolescent development are distinguished in functional, and structural aspects, which affect community members' physical and mental health[6]. In fact, children and adolescents living in poor environmental areas had higher levels of anxiety and depression[7]. lower self-concepts, and more so when the residential areas have higher rates of community crime [8]. In addition, the disorder of the physical environment, such as the construction of harmful environments and facilities, lacks of safety of walking, and the absence of parks have a negative impact on physical and mental health[9]. Meanwhile, the community physical environment that positively affects physical and mental health promotes mental health, including psychological well-being and cognitive and emotional resilience. It has also been reported that the development of children improves concentration and helps to improve life satisfaction and happiness by relieving the heavy stress of study(New York Times, 2015).

As such, the purpose of the certification of child and youth-friendly cities is to create a positive 
environment for the development of children. For example, if the green space in the area is maintained to create a child-friendly physical environment and encouraged rest and play, it is a space that can increase physical activities of all ages, not only children and adolescents, but also the disabled and old age.

Therefore, urban parks are provided with opportunities for activities in the natural environment. Children and adolescents share various play activities with their friends in parks and green spaces to promote peer relations. In addition, various amusement facilities, clean urban environment, and various convenient facilities and hospital systems have important effects on the development and growth of children. Child-friendly residential environments have been shown to have a significant impact on the physical and mental health of children[10].

Community involvement and awareness, attitudes and interactions with neighbors are also reported to affect the psychological well-being of children[11]. However, poor housing and community conditions have a negative impact impact on their physical and mental health. Thus, the economic, Insert comma after the word. and structural environment of the community can be. a result of influencing children and adolescents and increasing the level of satisfaction with their lives.

This study is focuses on improving the satisfaction of children lives on the physical and mental health dimensions of children and provide awareness and opportunities for urban environments and communities to live as a healthy and mature future generation leader. Therefore, the results of the study can help children and adolescents live happily, suggesting practical improvements and changes in child affinity to the level of community support.

This study is focusing to improve the satisfaction of children lives on the physical and mental health dimensions of children and provide awareness and opportunities for urban environments and communities to live as a healthy and mature future generation leader. It is also expected that various implications can be provided for practical improvement.

\subsection{Research Problem}

The research issues of this study are as follows.

First, what is the level of recognition of children in their rights based on the six major areas of childfriendly cities?

Second, what is the level of satisfaction of the children living in a child-friendly city?

\section{Research method}

\subsection{Study Subjects}

The data used in this study are the survey responses of children and adolescents from the B district of G city conducted from September 23, 2019 to October 29, 2019. A total of 505 respondents answered the survey, with 157 elementary school seniors, 157 middle school students, 164 high school students, and 27 out-of-school children.

\subsection{Measurement of Data}

The dependent variables of this study were measured for life satisfaction, and the variables were the six major areas of play and leisure, participation and civic awareness, safety and protection, health and social services, educational environment, and home environment. 


\subsubsection{Child-friendliness Degree}

The Korean Committee of UNICEF translated the measure proposed by UNICEF to create a childfriendly city and supplemented it to suit local characteristics. UNICEF developed and used measures based on the right to survive, protect. and participate in six major areas of child-friendly cities. The questions consist items on play and leisure (7 questions), participation and civic awareness (6 questions), safety and protection (15 questions), health and social services (8 questions), educational environment (23 questions), and family environment (5 questions). Each question consists of a three-point three-point Likert scale, where one point corresponds to "not at all" and three points for "very". The higher the score in each question, the higher the awareness of the rights of children.

\subsubsection{Residential Satisfaction, Life Satisfaction}

The level of satisfaction in life was measured according to the satisfaction level of the residential environment in the community by checking whether the services provided in each area for creating a child-friendly city were affecting the level of satisfaction among children and adolescents. Each item is a measure of a seven-point scale, which is the life satisfaction felt by the respondents.

\subsubsection{Demographic and Sociological Characteristics}

Sex birth year, residential area, family composition, nationality, etc. were investigated as factors of demographic and sociological characteristics. For sex, ' 0 ' was coded for males and ' 1 ' for females. Questions are single and open-ended types.

\subsection{Data analysis}

This study used SPSS 25.0 Statistical Program for data analysis. Frequency analysis and percentages were calculated to analyze the demographic characteristics, and technical statistics were performed to identify the overall variable characteristics. A -verification was conducted to examine the differences in major variables according to the characteristics. In addition, a random analysis of repeated measurements was conducted between groups according to the satisfaction items of children and adolescents, and a one-sided analysis was conducted for each satisfaction item. The final data was obtained by minimizing non-sampling error through processes such as editing, coding, cleaning, and data processing.

\section{Research Results}

\subsection{The Demographic and Sociological Characteristics of the Study Subjects}

The demographic and sociological characteristics of the study subjects were examined, and the sex ratio of children and adolescents, birth year, residence area, family composition, nationality, etc. were investigated. The gender status and family composition of children are as shown in [Table 1].

[Table 1] The Gender Status and Family Composition of Children (Unit : Number of people, \%)

\begin{tabular}{|c|c|c|c|c|c|}
\hline \multicolumn{2}{|c|}{ Sortation } & $\begin{array}{c}\text { Elementary school } \\
\text { students }\end{array}$ & $\begin{array}{c}\text { Middle school } \\
\text { students }\end{array}$ & High school students & $\begin{array}{c}\text { Children from } \\
\text { outside school }\end{array}$ \\
\hline \multicolumn{2}{|c|}{ All } & $157(31.1)$ & $156(30.9)$ & $165(32.7)$ & $27(5.3)$ \\
\hline \multirow{2}{*}{ Sex } & Male & $82(52.2)$ & $59(37.8)$ & $123(74.5)$ & $11(40.7)$ \\
\cline { 2 - 6 } & Female & $75(47.8)$ & $97(62.2)$ & $42(25.5)$ & $16(59.3)$ \\
\hline Family & Mother & $151(30.0)$ & $143(28.4)$ & $156(31.0)$ & $21(4.2)$ \\
\hline
\end{tabular}




\begin{tabular}{|c|c|c|c|c|c|}
\hline & Father & $144(28.6)$ & $147(29.2)$ & $151(30.0)$ & $15(3.0)$ \\
\cline { 2 - 6 } & $\begin{array}{c}\text { Brother } \\
\text { Sister }\end{array}$ & $131(26.0)$ & $139(27.6)$ & $132(26.2)$ & $16(3.2)$ \\
\cline { 2 - 6 } & Grandfather & $16(3.2)$ & $5(1.0)$ & $3(0.6)$ & $1(0.2)$ \\
\cline { 2 - 6 } & Grandmother & $22(4.4)$ & $13(2.6)$ & $13(2.6)$ & $2(0.4)$ \\
\cline { 2 - 6 } & Other else & $7(1.4)$ & $10(2.0)$ & $1(0.2)$ & $0(0.0)$ \\
\hline
\end{tabular}

Of the 505 respondents, 54.5 percent were male with 275 respondents, and 45.6 percent were female with 230 respondents, indicating that the number of males was higher. Among the elementary school students, $52.5 \%$ are men and $47.8 \%$ are women. Among the middle school students, $37.8 \%$ are men and $62.2 \%$ are women. In high school, $74.5 \%$ are men and $25.5 \%$ are women responded more. For the outof-school children and youth, $40.7 \%$ are men and $59.3 \%$ are women. The radio of family members is $93.2 \%$ for mothers, $90.4 \%$ for fathers, $83 \%$ for brothers and sisters, $14 \%$ for grandparents and $0.4 \%$ for other family member, which means that many people living with their parents.

\subsection{Recognition of Rights of Children and Adolescents in Each of the Six Major Areas}

\subsubsection{Awareness of Play and Leisure Areas}

In the six areas of child-friendly cities, the level of rights recognition for detailed services of play and leisure was identified. The play and leisure areas consist of questions whether there is space available for children and adolescents in community housing are as shown in [Table 2].

[Table 2] The Play and Leisure Areas (Unit : \%)

\begin{tabular}{|c|l|c|c|c|c|}
\hline \multirow{2}{*}{ Num } & \multicolumn{1}{|c|}{ Question } & \multicolumn{3}{|c|}{ Children } \\
\cline { 3 - 6 } & & $\begin{array}{c}\text { Elementary } \\
\text { school } \\
\text { students }\end{array}$ & $\begin{array}{c}\text { Middle } \\
\text { school } \\
\text { students }\end{array}$ & $\begin{array}{c}\text { High school } \\
\text { students }\end{array}$ & $\begin{array}{c}\text { Children from } \\
\text { outside school }\end{array}$ \\
\hline 1 & I have free time to rest or play & 77.7 & 72.4 & 58.2 & 66.7 \\
\hline 2 & $\begin{array}{l}\text { There are safe places in our community where I can exercise } \\
\text { and play (e.g., playgrounds, playgrounds, sports facilities, } \\
\text { etc.). }\end{array}$ & 75.8 & 63.9 & 57.0 & 51.9 \\
\hline 3 & $\begin{array}{l}\text { Our community playground is available to children with } \\
\text { physical disabilities. }\end{array}$ & 19.7 & 18.1 & 17.0 & 11.1 \\
\hline 4 & $\begin{array}{l}\text { There's a place in our community where I have access to } \\
\text { nature (e.g., forests, trees, etc) }\end{array}$ & 65.6 & 60.0 & 60.6 & 44.4 \\
\hline 5 & $\begin{array}{l}\text { There are various cultural/religious events in our community } \\
\text { where I can participate or watch. }\end{array}$ & 37.6 & 30.3 & 32.1 & 22.2 \\
\hline 6 & $\begin{array}{l}\text { Our community has out-of-school programs, meetings and } \\
\text { activities that I can participate in. }\end{array}$ & 49.0 & 34.2 & 27.9 & 48.1 \\
\hline 7 & $\begin{array}{l}\text { A safe place for me to play (e.g., playgrounds, playgrounds, } \\
\text { etc.) is just around the house. }\end{array}$ & 85.4 & 80.0 & 62.8 & 63.0 \\
\hline
\end{tabular}

※ Average score: $1=$ Not at all, $2=$ Sometimes, $3=$ Very.

$※$ Positive response rate: Percentage of responses to positive responses (very)

As a result of the analysis, the lowest level of recognition of rights in the play and leisure areas of children living in District B of G city could be identified as the absence of space available to children with physical disabilities. As a result of these similar items, the provision of various cultural religious programs available to the community was also not high. Improvements and efforts in these two subareas will be needed in the future. 


\subsubsection{Awareness of the Domain of Participation and Civic Awareness}

Among the six areas of child-friendly cities, the level of rights recognition for participation and civic awareness was identified. The area of participation and civic awareness is a decision-making process that determines important issues in the community, consisting of whether the opinions of children are reflected and whether they actively provide important matters in the region related to children. The level of recognition of rights of children in the area is as shown in [Table 3].

[Table 3] The Level of Recognition of Rights of Children in the Area (Unit : \%)

\begin{tabular}{|l|l|c|c|c|c|}
\hline \multirow{2}{*}{ Num } & \multicolumn{1}{|c|}{ Question } & \multicolumn{3}{|c|}{ children } \\
\cline { 3 - 6 } & & $\begin{array}{c}\text { Elementary } \\
\text { school } \\
\text { students }\end{array}$ & $\begin{array}{c}\text { Middle } \\
\text { school } \\
\text { students }\end{array}$ & $\begin{array}{c}\text { High school } \\
\text { students }\end{array}$ & $\begin{array}{c}\text { Children from } \\
\text { outside school }\end{array}$ \\
\hline 1 & $\begin{array}{l}\text { Our community offers me the opportunity to participate in the } \\
\text { task of transforming the region. }\end{array}$ & 24.2 & 19.2 & 11.5 & 18.5 \\
\hline 2 & $\begin{array}{l}\text { Our community offers me the opportunity to participate in } \\
\text { planning or making decision for the region. }\end{array}$ & 26.1 & 19.9 & 10.9 & 22.2 \\
\hline 3 & $\begin{array}{l}\text { Our community (local councils, heads of local governments, } \\
\text { etc.) investigates my opinions on living conditions or areas. }\end{array}$ & 12.7 & 18.6 & 12.7 & 14.8 \\
\hline 5 & $\begin{array}{l}\text { Our community listens my opinion on the budget for programs } \\
\text { and services for children. }\end{array}$ & 21.7 & 17.9 & 7.3 & 14.8 \\
\hline 6 & $\begin{array}{l}\text { I have heard about children's rights through various media (local } \\
\text { TV, radio, publications, festivals, events, etc.).through the } \\
\text { internet. }\end{array}$ & 31.8 & 26.9 & 23.6 & 29.6 \\
\hline
\end{tabular}

※ Average score: $1=$ Not at all, $2=$ Sometimes, $3=$ Very.

※ositive response rate: Percentage of responses to positive responses (very)

As a result of the analysis, the response on 'I can see what happens on the Internet, both inside and outside our community' in terms of the level of participation of children living in District B of G city and awareness of civil was the highest. The response rate for 'our community (local council, local government heads, etc.) surveyed my living environment or local opinion' was the lowest. From this perspective, it is necessary to make efforts to improve the level of participation of children who are members of the community to develop into a child-friendly city in the future.

\subsubsection{Recognition of Safety and Protection Areas}

The level of rights recognition for safety and protection services was identified of the six areas of child-friendly cities. Safety and protection areas consist of items on the level of safety felt in the community. The level of recognition of rights of children and adolescents in the area is as shown in [Table 4].

The analysis showed that the overall response for 'I know where to report in case of danger to me and who to ask for help' was the highest while for 'regional society is safe for me to walk or ride a bicycle' is the lowest in terms of their level of awareness of the safety and protection. Looking at the above results, it is necessary to actively provide various security-related services or counseling services for damage to create a child- and youth-friendly city in the future, as well as make efforts to create a safe physical environment. 
[Table 4] The Level of Recognition of Rights of Children and Adolescents in the Area (Unit : \%)

\begin{tabular}{|c|c|c|c|c|c|}
\hline \multirow[b]{2}{*}{ Num } & \multirow[b]{2}{*}{ Question } & \multicolumn{4}{|c|}{ Children } \\
\hline & & $\begin{array}{l}\text { Elementary } \\
\text { school } \\
\text { students }\end{array}$ & $\begin{array}{l}\text { Middle } \\
\text { school } \\
\text { students }\end{array}$ & $\begin{array}{l}\text { High school } \\
\text { students }\end{array}$ & $\begin{array}{l}\text { Children from } \\
\text { outside school }\end{array}$ \\
\hline 1 & $\begin{array}{l}\text { I know where to report and who to ask for help when there is } \\
\text { a danger to me. }\end{array}$ & 91.1 & 84.0 & 77.6 & 59.3 \\
\hline 2 & I feel safe from gangsters/arms & 60.5 & 53.8 & 55.2 & 55.6 \\
\hline 3 & $\begin{array}{l}\text { I feel safe from violence and abuse. } \\
\text { *Language, physical, or sexual violence and abuse. }\end{array}$ & 64.3 & 60.3 & 57.6 & 40.7 \\
\hline 4 & I feel safe from kidnapping & 59.2 & 50.0 & 53.3 & 29.6 \\
\hline 5 & I'm not worried about being bullied by my friend. & 58.0 & 59.0 & 64.8 & 55.6 \\
\hline 6 & $\begin{array}{l}\text { I feel safe from dangerous drugs (e.g., drugs, hallucinogens, } \\
\text { etc.). }\end{array}$ & 70.1 & 73.1 & 69.7 & 63.0 \\
\hline 7 & Our community is safe for me to walk or ride a bicycle. & 52.2 & 50.0 & 44.2 & 48.1 \\
\hline 8 & $\begin{array}{l}\text { Children in our community are respected regardless of race, } \\
\text { religion, nationality, ethnicity, culture and disability. }\end{array}$ & 52.2 & 50.0 & 41.8 & 37.0 \\
\hline 9 & $\begin{array}{l}\text { Public transportation in our community (e.g. buses, subways, } \\
\text { etc.) is safe for me to use. }\end{array}$ & 66.9 & 69.9 & 64.2 & 70.4 \\
\hline 10 & $\begin{array}{l}\text { There are adults (other than family) in our community who I } \\
\text { can ask for help with abuse or violence. }\end{array}$ & 83.4 & 67.3 & 61.2 & 63.0 \\
\hline 11 & $\begin{array}{l}\text { Our community protects me from doing dangerous things } \\
\text { (e.g., unsafe things that threaten my health). }\end{array}$ & 64.3 & 54.5 & 46.1 & 37.0 \\
\hline 12 & $\begin{array}{l}\text { Our community informs me of safety behavior in disaster } \\
\text { situations (e.g., floods, earthquakes, etc.). }\end{array}$ & 70.7 & 60.9 & 4.8 & 48.1 \\
\hline 13 & $\begin{array}{l}\text { My community teaches me the problems of the adverse } \\
\text { effects* of the Internet. *selective/violent content, illegal } \\
\text { downloads, hacking, malicious comments, etc. }\end{array}$ & 68.2 & 44.2 & 37.6 & 25.9 \\
\hline 14 & $\begin{array}{l}\text { Our community provides a place for homeless children to eat, } \\
\text { wash and sleep. }\end{array}$ & 36.9 & 34.0 & 23.0 & 33.3 \\
\hline 15 & $\begin{array}{l}\text { A separate legal system is applied to children in legal trouble, } \\
\text { which is different from adults. }\end{array}$ & - & 32.1 & 35.2 & 40.7 \\
\hline
\end{tabular}

※ Average score: $1=$ Not at all, $2=$ Sometimes, $3=$ Very. ※ Positive response rate: Percentage of responses to positive responses (very)

\subsubsection{Recognition of Health and Social Services Areas}

The level of rights recognition for detailed health and social services was identified in the six areas of child-friendly cities. The health and social service areas consist of questions about medical services and environmental services in the community. The level of recognition of rights of children and adolescents in the area is as shown in [Table 5].

[Table 5] The Level of Recognition of Rights of Children and Adolescents in the Area (Unit : \%)

\begin{tabular}{|c|l|c|c|c|c|}
\hline \multirow{2}{*}{ Num } & \multicolumn{1}{|c|}{ Question } & \multicolumn{4}{|c|}{ Children } \\
\cline { 3 - 6 } & $\begin{array}{c}\text { Elementary } \\
\text { school } \\
\text { students }\end{array}$ & $\begin{array}{c}\text { Middle } \\
\text { school } \\
\text { students }\end{array}$ & $\begin{array}{c}\text { High school } \\
\text { students }\end{array}$ & $\begin{array}{c}\text { Children from } \\
\text { outside school }\end{array}$ \\
\hline 1 & $\begin{array}{l}\text { I know about child mental health services (e.g., counseling, } \\
\text { etc.). }\end{array}$ & 46.5 & 36.5 & 35.8 & 40.7 \\
\hline 2 & I can get sex education through experts. & 58.0 & 48.1 & 45.5 & 44.4 \\
\hline
\end{tabular}




\begin{tabular}{|c|l|c|c|c|c|}
\hline 3 & $\begin{array}{l}\text { There is a public toilet in my community that I can use safely } \\
\text { and easily. }\end{array}$ & 42.7 & 38.5 & 44.8 & 51.9 \\
\hline 4 & $\begin{array}{l}\text { There is no problem with garbage and dirty water in our } \\
\text { community. }\end{array}$ & 26.1 & 30.1 & 35.8 & 33.3 \\
\hline 5 & $\begin{array}{l}\text { There is no problem with garbage and dirty water in our } \\
\text { community. }\end{array}$ & 80.3 & 77.6 & 64.8 & 51.9 \\
\hline 6 & $\begin{array}{l}\text { There are no problems with smoke and odour in our } \\
\text { community and they are clean. }\end{array}$ & 22.3 & 30.1 & 24.8 & 33.3 \\
\hline 7 & $\begin{array}{l}\text { There is a place in our community where I can get a checkup or } \\
\text { treatment when I'm sick. }\end{array}$ & 86.0 & 81.4 & 77.0 & 66.7 \\
\hline 8 & My community gives me the vaccinations Ineed. & 82.8 & 76.3 & 57.6 & 48.1 \\
\hline
\end{tabular}

※ Average score: $1=$ Not at all, $2=$ Sometimes, $3=$ Very. ※ositive response rate: Percentage of responses to positive responses (very)

The analysis showed the highest positive response rate for 'there is a place where I can be examined or treated when I am sick' in terms of their level of rights awareness in the health and social service areas. The positive response rate for 'our community has no problems with smoke and odors' is the lowest. Looking at the above results, The community is satisfied with the level of health care, but not with the problems associated with environmental pollution handling such as smoke and odors. Active efforts are needed to resolve future environmental problems in the community.

\subsubsection{Awareness of the Educational Environment Area}

The level of rights recognition for detailed education environment services was confirmed in the six areas of child-friendly cities. The education environment area consists of items related to services for public education. The level of rights awareness among children and adolescents in the area is as shown in [Table 6].

[Table 6] The Level of Rights Awareness among Children and Adolescents in the Area (Unit : \%)

\begin{tabular}{|c|c|c|c|c|c|}
\hline \multirow[b]{2}{*}{ Num } & \multirow[b]{2}{*}{ Question } & \multicolumn{4}{|c|}{ Children } \\
\hline & & $\begin{array}{c}\text { Elementary } \\
\text { school } \\
\text { students }\end{array}$ & $\begin{array}{l}\text { Middle school } \\
\text { students }\end{array}$ & $\begin{array}{l}\text { High school } \\
\text { students }\end{array}$ & $\begin{array}{l}\text { Children from } \\
\text { outside school }\end{array}$ \\
\hline 1 & I go to school. & 100.0 & 96.2 & 94.5 & 11.1 \\
\hline 2 & $\begin{array}{l}\text { I can buy basic school supplies (e.g., notebooks, } \\
\text { notebooks, books, etc.) for school when I need them. }\end{array}$ & 94.3 & 93.6 & 87.3 & 63.0 \\
\hline 3 & $\begin{array}{l}\text { I can convey my opinion to the important making } \\
\text { decision process of the school. }\end{array}$ & 75.8 & 63.5 & 57.6 & 29.6 \\
\hline 4 & $\begin{array}{l}\text { When I want, I get enough attention and help from my } \\
\text { teacher. }\end{array}$ & 78.3 & 71.8 & 67.3 & 40.7 \\
\hline 5 & We treat men and women equally in our school. & 67.5 & 39.1 & 43.6 & 29.6 \\
\hline 6 & In my school, the teacher listens to my opinion. & 80.3 & 70.5 & 58.2 & 25.9 \\
\hline 7 & $\begin{array}{l}\text { In our school, we teach about proper living habits (e.g., } \\
\text { eating habits, etc.). }\end{array}$ & 77.7 & 69.2 & 58.8 & 33.3 \\
\hline 8 & Our school teaches how to protect the environment. & 77.1 & 71.2 & 53.9 & 29.6 \\
\hline 9 & We can get sex education in our school. & 80.3 & 76.9 & 55.8 & 48.1 \\
\hline 10 & Our school has enough clean water to drink and wash. & 78.3 & 76.3 & 76.4 & 48.1 \\
\hline 11 & Our school has a clean toilet that is easy and safe to use. & 61.8 & 62.8 & 63.0 & 33.3 \\
\hline
\end{tabular}




\begin{tabular}{|c|l|c|c|c|c|}
\hline 12 & $\begin{array}{l}\text { In our school we respect children regardless of race, } \\
\text { religion, nationality, culture, etc. }\end{array}$ & 74.5 & 63.5 & 64.2 & 37.0 \\
\hline 13 & $\begin{array}{l}\text { In our school, children with disabilities are respected, } \\
\text { and treated the same. }\end{array}$ & 65.0 & 57.1 & 60.6 & 37.0 \\
\hline 14 & $\begin{array}{l}\text { Our school has experts (e.g., counselors) who can talk } \\
\text { about their worries. }\end{array}$ & 63.1 & 79.5 & 65.5 & 44.4 \\
\hline 15 & Children with disabilities can attend our school. & 77.1 & 68.6 & 47.3 & 44.4 \\
\hline 16 & $\begin{array}{l}\text { Our school teaches children without corporal } \\
\text { punishment. }\end{array}$ & 68.8 & 53.8 & 41.7 & 33.3 \\
\hline 17 & $\begin{array}{l}\text { In our school, there is no risk of being bullied or } \\
\text { ostracized and we respect each other. }\end{array}$ & 57.3 & 65.4 & 56.4 & 18.5 \\
\hline 18 & $\begin{array}{l}\text { In my school, the area where I live provides programs } \\
\text { for future jobs. }\end{array}$ & 63.7 & 76.3 & 64.8 & 33.3 \\
\hline 19 & $\begin{array}{l}\text { Our school has free time to play, exercise, and rest with } \\
\text { friends. }\end{array}$ & 91.1 & 89.1 & 81.2 & 44.4 \\
\hline 20 & $\begin{array}{l}\text { There is a library (including a school library) available } \\
\text { to me in my community. }\end{array}$ & 93.6 & 24.4 & 22.4 & 59.3 \\
\hline 21 & $\begin{array}{l}\text { I learn about children's rights and the United Nations } \\
\text { Convention on the Rights of the Child at school. }\end{array}$ & 35.7 & 77.1 & 40.6 & 25.9 \\
\hline 22 & $\begin{array}{l}\text { Our community supports me to attend school without } \\
\text { earning my own education. }\end{array}$ & 56.1 & $\begin{array}{l}\text { There is a place in my community where I can be } \\
\text { educated. }\end{array}$ & 77.1 & 37.0 \\
\hline
\end{tabular}

※ Average score: $1=$ Not at all, $2=$ Sometimes, $3=$ Very. $※$ Positive response rate: Percentage of responses to positive responses (very)

The analysis showed that the overall positive response rate for 'I can buy basic school supplies when I need them' has the highest level of rights recognition for the educational environment of children living in District B of G city, and that 'I learn about children's rights and the UN Convention on the Rights of the Child' was the lowest. Looking at the above results, we can see that education services on the level of education for children rights should be provided. Furthermore, it is necessary to provide not only the education but human rights awareness as well among the children.

\subsubsection{Awareness of the Home Environment Area}

The level of rights recognition for detailed home environment services was identified in the six areas of child-friendly cities. The domain of the home environment consists of items on the family life. The level of rights awareness among children in the area is as shown in [Table 7].

[Table 7] The Level of Rights Awareness among Children in the Area (Unit : \%)

\begin{tabular}{|c|c|c|c|c|c|}
\hline \multirow[b]{2}{*}{ Num } & \multirow[b]{2}{*}{ Question } & \multicolumn{4}{|c|}{ Children } \\
\hline & & $\begin{array}{l}\text { Elementary } \\
\text { school } \\
\text { students }\end{array}$ & $\begin{array}{l}\text { Middle } \\
\text { school } \\
\text { students }\end{array}$ & $\begin{array}{l}\text { High school } \\
\text { students }\end{array}$ & $\begin{array}{l}\text { Children from } \\
\text { outside school }\end{array}$ \\
\hline 1 & $\begin{array}{l}\text { There's plenty of clean water in my house for me to } \\
\text { drink. }\end{array}$ & 97.5 & 94.9 & 88.5 & 77.8 \\
\hline 2 & $\begin{array}{l}\text { There is a clean toilet I can use at my house or near my } \\
\text { house. }\end{array}$ & 79.0 & 82.7 & 82.4 & 70.4 \\
\hline 3 & There is enough water to wash in my house. & 97.5 & 94.2 & 90.9 & 77.8 \\
\hline 4 & $\begin{array}{l}\text { The air in my house is clean and free from smoke and } \\
\text { air pollution. }\end{array}$ & 80.3 & 74.4 & 70.3 & 70.4 \\
\hline
\end{tabular}




\begin{tabular}{|c|l|c|c|c|c|}
\hline 5 & Our house can use electricity & 98.1 & 94.9 & 90.3 & 85.2 \\
\hline 6 & My house is able to stay for all seasons. & 89.8 & 90.4 & 86.7 & 81.5 \\
\hline 7 & $\begin{array}{l}\text { My house is an economical and sustainable place to } \\
\text { live. }\end{array}$ & 88.5 & 84.0 & 83.6 & 63.0 \\
\hline 8 & $\begin{array}{l}\text { There is enough space in my house (e.g., play area, } \\
\text { study room, bedroom). }\end{array}$ & 87.3 & 89.1 & 83.0 & 63.0 \\
\hline 9 & My house is safe for me to live. & 93.0 & 88.5 & 87.9 & 74.1 \\
\hline
\end{tabular}

※ Average score: $1=$ Not at all, $2=$ Sometimes, $3=$ Very.

※ Positive response rate: Percentage of responses to positive responses (very)

The analysis showed that the overall positive response rate for 'our house can use electricity' has the highest level of rights awareness of the home environment of children living in District B of G city, and that 'our air is clean and there is no smoke and air pollution' was the lowest. Looking at the above results, children are satisfied with the use of electricity and drinking water needed for family life, but their satisfaction with pollution of smoke and air is relatively low. Efforts to supplement environmental pollution in the exploration task are needed for these results continuously in the future.

\subsection{Satisfaction Level of Children}

The level of satisfaction of children and adolescents is a seven-point scale the highest the level of satisfaction. Therefore, the level of satisfaction was measured at two levels of satisfaction. The results of the satisfaction level are as shown in [Table 8].

[Table 8] The Results of the Satisfaction Level (Unit : Point)

\begin{tabular}{|c|c|c|}
\hline Sortation & Average & Average scale \\
\hline Satisfaction with the residential area & 5.47 & 4.37 \\
\hline Satisfaction level of life & 5.18 & 1.42 \\
\hline
\end{tabular}

※ The highest the score on the 7-point scale its the higher the satisfaction level.

Children scored more than five points on both levels of satisfaction. This shows that children are now satisfied with their residential areas and their lives.

\section{Discussion and Conclusions}

The purpose of this study is to examine how much children are aware of their rights and their satisfaction in life in the urban community environment of children, and to analyze in detail the six major areas of child and youth-friendly cities so that they can be supplemented in a constructive and concrete way for child and youth-friendly cities. The results of the analysis of 505 children living in B district of G city are as follows. First, elementary school students were found to have higher awareness of children's rights and satisfaction than middle school, high school, and out-of-school students. Elementary school students scored high in their home environment, educational environment, play and leisure, safety and protection, and participation. These results show that they are effective when education and support for children's rights are provided from lower grades. It also suggest the need to provide sustainable child-friendly services at the stage of growth development. Senior students should be provided with services on child-friendly city through monitoring support and direct participation in establishing and strengthening rights education programs for children. Second, there is a need to focus 
on supporting education and expanding health and social services, along with the emphasis of family support services. The living environment of children is important, so as the importance of home, education, and health environment. Furthermore, a physically prepared environment is essential in a child-friendly city. Third, the satisfaction on the rights of children were different according to school level. The home environment, educational environment, and play and leisure were important for elementary school students, in this order. For middle and high school students, the order of importance is the home environment, educational environment, and safety and protection. For out-of-school students, the order is home environment, play and leisure, and health and social service. These results should consist of complex interventions and approaches to the creation of child-friendly cities that consider various aspects of education, safety and protection, play and leisure, health and social services, etc. in terms of child-friendly city rights.

The subjects of the study are centered on children in the B district of G Metropolitan City, so there may be some limitations in the representation of the sample. While it is focused on the children's rights, it has failed to consider the various variables affecting life satisfaction among children living in the cities.

\section{References}

[1] Child Poverty in Perspective: An Overview of Child Well-Being in Rich Countries, UNICEF Inocenti Research Centre, (2007)

[2] P. Christensen, M. O' Brien, Children in the City : Home, Neighbourhood and Community, Routledge, (2002)

[3] K. Malone, A Key Player in A Global Movement for Child Friendly Cities : Routledge, (2006)

[4] E. Riggio, Child friendly cities: good governance in the best interests of the child, Environment \& Urbanization, (2002), Vol.14, No.2, pp.45-58, https://doi.org/10.1177/095624780201400204

[5] Child Well-Being in Rich Countries: A Comparative Overview, UNICEF Innocenti's Complete Catalogue of Research and Reports ,UNICEF Office of Research, (2013)

[6] T. H. Yoon, Regional Health Inequalities in Korea The Status and Policy Tasks, Journal of Critical Social Welfare, (2010), No.30, pp.49-77.

[7] H. A. Kang, Poverty, Risky Environments of Disadvantageous Neighborhoods, and Adolescents' Depression and Anxiety, Korean Journal of Social Welfare Studies, (2010), Vol.41, No.3, pp.327-348.

[8] H. A. Kang, C. R. Noh, A Study of Regional Effects on the Self-concept of Youth, Studies on Korean Youth, (2012), Vol.23, No.4, pp.101-129.

[9] Y. M. Kim, Analysis of Neighborhood Disorder Influences Upon Adolescent Depression, Social Science Research, (2008), Vol.24, No.4, pp.29-50.

[10] K. Aminzadeh, S. Denny, J. Utter, T. L. Milfont, S. Ameratunga, T. Teevale, T. Clark, Neighbourhood Social Capital and Adolescent Self-reported Wellbeing in New Zealand: a Multilevel Analysis, Social Science \& Medicine, (2013), Vol.84, pp.13-21, DOI: 10.1016/j.socscimed.2013.02.012

[11] A. K. Ivert, M. T. Levander, Adolescents'Perceptions of Neighbourhood Social Characteristics- Is There a Corelation with Mental Health, Child Indicators Research, (2014), Vol.7, No.1, pp.177-192. 